\title{
STRATEGI MARKETING MIX DALAM MENGHADAPI PANDEMI COVID-19 (STUDI KASUS PADA CAFE JOLLY COFFEE SURABAYA)
}

\author{
Siti Nur Wahyu Ningsih \\ Universitas Islam Negeri Sunan Ampel Surabaya \\ yuni.snw@gmail.com \\ Aida Octavia Milasari \\ Universitas Islam Negeri Sunan Ampel Surabaya \\ aida.octavia98@gmail.com \\ Muchammad Saifuddin \\ Universitas Islam Negeri Sunan Ampel Surabaya \\ saifuddin@uinsby.ac.id
}

\begin{abstract}
The cafe business in Indonesia is increasingly increased its growth. This is a business field for business activists. Surely a cafe has its own marketing system or what we can call a Marketing Mix. The purpose of this study is to identify the implementation of marketing strategies in cafes in Indonesia, especially in Surabaya. This research uses qualitative methods, namely through observation, document study and interviews with several relevant informants. The results of this study indicate that Cafe Jolly Coffee Surabaya uses a marketing strategy which I believe is appropriate to attract consumer interest and is also used to compete in the cafe sector.

Keywords: Cafe; Covid-19, Marketing Strategy;Marketing Mix.
\end{abstract}

\section{PENDAHULUAN}

Perkembangan bisnis di Indonesia yang meningkat pesat, menjadikan kesempatan bagi pengusaha untuk menanamkan modal dan membuka jenis usaha cafe. Di era globalisasi ini dimana persaingan dalam berbagai bidang apalagi yang berkaitan dengan ekonomi amatlah kompetitif. Ruang lingkup ekonomi sangatlah luas, terutama kalau berbicara tentang bidang usaha. Dimana bidang usaha hampir dilakukan semua orang mengingat pendapatan didapatkan dari bidang usaha. Globalisasi terjadi di segala aspek kehidupan seperti ekonomi, sosial budaya, politik, ilmu pengetahuan, teknologi, hukum dan sebagainya. Bidang usaha selalu menarik untuk dibahas, khususnya di bidang usaha Cafe.

Cafe sendiri terbentuk akibat hasrat seseorang yang menjadi pelaku dalam bidang usaha yang digemari oleh masyarakat khususnya untuk kalangan anak muda. Adanya keuntungan dalam usaha cafe membuat beberapa pelaku berlomba-lomba untuk mendirikan jenis usaha cafe ini. Menjalankan bisnis cafe tidak hanya terpaku pada tempat tujuan yang menawarkan suasana beda, melainkan juga makanan dan juga tempat nongkrong yang nyaman. Inilah yang dijadikan landasan bagi beberapa pelaku usaha khususnya yang bergerak di bidang cafe untuk meningkatkan pangsa 
pasar agar terciptanya sebuah peluang bisnis untuk meningkatkan kesejahteraan baik di pihak cafe maupun sinergi bagi yang membutuhkan (konsumen). Pastinya setiap perusahaan tidak serta merta membuka sebuah peluang bisnis tanpa adanya sebuah landasan strategi sistem yang nantinya akan mengoperasikan bidang usaha tersebut. Maka penerapan strategi yang cocok diterapkan agar bisa bersaing di kanca persaingan lokal maupun nasional adalah dengan diterapkannya metode Marketing Mix.

Seperti yang kita tahu metode Marketing Mix ialah salah satu strategi yang dapat dilakukan perusahaan untuk mengetahui seberapa tingkat pemasaran yang akan dilakukan perusahaan untuk meningkatkan pangsa pasar. Hal ini terjadi lantaran perusahaan perlu melakukan persaingan dengan perusahaan lainnya yang sama ketat bergerak di bidang cafe, sehingga pelaku bisnis perlu menyusun strategi yang dapat meningkatkan pangsa pasarnya.

Sebuah strategi juga diperlukan dalam mengatasi suatu situasi atau kondisi yang tidak terduga seperti yang sedang terjadi saat ini yaitu adanya krisis pandemi covid-19. Pandemi covid-19 ini merupakan suatu kondisi dimana terjadinya penyebaran virus yang berlangsung dengan cepat dan masif serta berdampak pada kematian. Dengan melihat dari cepatnya penyebaran covid-19 ini memaksa pemerintah untuk segera menerapkan Pembatasan Sosial Berskala Besar (PSBB) di seluruh wilayah. Namun dengan adanya PSBB tersebut membawa dampak yang begitu besar terhadap perekonomian di suatu negara. Hal ini dikutip dari laman berita Kompas.com yang menyatakan bahwa pertumbuhan ekonomi di Indonesia minus 3,49 persen pada kuartal III-2020. Salah satu sektor ekonomi yang terdampak adalah pelaku usaha di bidang makanan dan minuman seperti restoran, frenchise makanan atau minuman, dan kafe. Tidak sedikit dari bisnis - bisnis tersebut yang mengalami kerugian bahkan harus sampai menutup bisnisnya tersebut akibat pandemi covid-19 ini.

\section{KAJIAN PUSTAKA \\ Strategi Pemasaran}

Strategi pemasaran sebagai suatu mindset pemasaran yang akan digunakan untuk mencapai tujuan pemasaran, dimana di dalamnya terdapat strategi menjuru mengenai pasar sasaran, penetapan posisi, bauran pemasaran, dan budget untuk pemasaran. (Philip Kotler, 2019). Pemasaran cafe itu selalu terdiri dari beberapa aktivitas yang bertujuan untuk menarik calon konsumen agar tertarik untuk membeli produk yang ditawarkan.

Selain itu adanya juga kegiatan promosi yang biasanya merupakan komponen prioritas dalam manajemen pemasaran (Putri dan Muchammad Saifuddin, 2020). 
Dengan adanya promosi maka konsumen akan mengetahui perusahaan meluncurkan produk baru yang akan mempengaruhi konsumen untuk melakukan pembelian.

Dalam menghadapi persaingan yang ketat, strategi perlu diterapkan oleh pelaku usaha. Pihak Cafe Jolly Coffee, Surabaya menerapkan strategi STP. STP (Segmenting, Targeting, and Positioning). Sebagai bentuk strategi pemasaran produk ataupun jasa akan di jelaskan sebagai berikut:

1. Segmenting adalah proses mengelompokkan pasar keseluruhan yang heterogen menjadi kelompok atau segmen yang memiliki kesamaan dalam hal kebutuhan, keinginan, perilaku, dan respon terhadap program pemasaran secara spesifik.

2. Targeting, diartikan sebagai kegiatan menentukan pasar sasaran, yaitu tindakan memilih satu atau lebih segmen untuk dilayani.

3. Positioning, yaitu bagaimana perusahaan menjelaskan posisi produk kepada konsumen. Apa beda produk perusahaan di bandingkan kompetitor dan apa saja keunggulannya.

\section{Marketing Mix}

Marketing mix (bauran pemasaran) merupakan kegiatan pemasaran yang terpadu, menunjang satu sama lain dengan cara mempengaruhi konsumen untuk membeli suatu produk/jasa. Menurut Basu Swastha dan Ibnu Sukotjo, bauran pemasaran adalah kombinasi dari empat variabel atau kegiatan yang merupakan inti dari sistem pemasaran yakni produk, struktur harga, kegiatan promosi dan sistem distribusi.

Menurut Philip Kotler (2019:19), bauran pemasaran adalah sekumpulan alat pemasaran 4P (Product, Price, Place, Promotion) yang digunakan perusahaan dalam rangka mencapai tujuan pemasaran sesuai dengan pasar sasaran yang telah ditetapkan. Selain komponen 4P terdapat penambahan komponen marketing mix seiring berkembangnya sejumlah penelitian. Menurut Lupiyoadi dan Hamdani (2008:70) marketing mix terdiri dari 7P (product, price, promotion, place, people, process, physical evidence) di bidang jasa yang saling mempengaruhi satu sama lain sehingga bila salah satu tidak tepat pengorganisasian nya maka akan mempengaruhi strategi pemasaran secara keseluruhan.

Setiap perusahaan selalu berusaha untuk bertahan, berkembang dan mampu bersaing. Perusahaan selalu menetapkan strategi pemasarannya karena kegiatan pemasaran yang dilakukan tersebut diarahkan untuk mencapai tujuan dari pemasaran perusahaan yang dapat mempengaruhi tingkat pertambahan laba yang diperoleh perusahaan dalam waktu jangka panjang. Salah satu unsur dalam kegiatan pemasaran terpadu adalah bauran pemasaran karena merupakan yang paling banyak diterapkan di perusahaan. 


\section{Corona Viruses Disease (COVID-19)}

Pada bulan Desember tahun 2019, sebuah virus baru muncul di permukaan bumi. Berawal dari Wuhan, Cina. World Health Organization (WHO) menjelaskan bahwa Coronaviruses (Cov) adalah virus yang menginfeksi sistem pernapasan. Infeksi virus ini disebut COVID-19. Penyebaran virus ini sangat cepat, bahkan saat ini penyebarannya sudah mencapai lintas negara. Sampai saat ini terdapat 188 negara yang telah mengkonfirmasi terkena virus Corona. Termasuk salah satunya adalah Negara Indonesia.

Virus corona atau Covid-19 pertama kali ditemukan di Wuhan, China pada akhir 2019 lalu. Penyebaran virus yang belum ditemukan penawarnya itu hingga kini tak terkendali. Sudah 200 lebih Negara di dunia melaporkan adanya kasus terpapar virus corona. Di Indonesia kasus ini pertama kali ditemukan pada dua warga Depok, Jawa Barat awal Maret lalu. Dalam waktu dua bulan, jumlah kasus positif mencapai lebih dari 13.000 kasus. Cepatnya penyebaran virus ini di Indonesia karena banyak warga yang tak mengikuti imbauan untuk tetap di rumah, padahal pemerintah menginstruksikan masyarakat salah satunya untuk melakukan social distancing atau menjaga jarak. Bila instruksi ini tidak dipatuhi, risiko penularan akan membesar.

Hingga saat ini kasus covid-19 di Indonesia terus mengalami kenaikan, menurut data kementerian melalui berita terkini Kompas.com tercatat pada tanggal 21 Desember 2020, Indonesia mencatat 132.895 kasus infeksi sepanjang desember atau rata-rata 6.328 per hari. secara total melaporkan 671.778 kasus positif covid19, kasus kematian sebanyak 20.085 dan 104.809 kasus aktif atau pasien yang masih dalam perawatan, sedangkan orang yang dinyatakan sembuh sebanyak 546.884 orang. Berikut penjelasan grafik kenaikan angka corona yang kian hari makin meningkat pada gambar 1 .

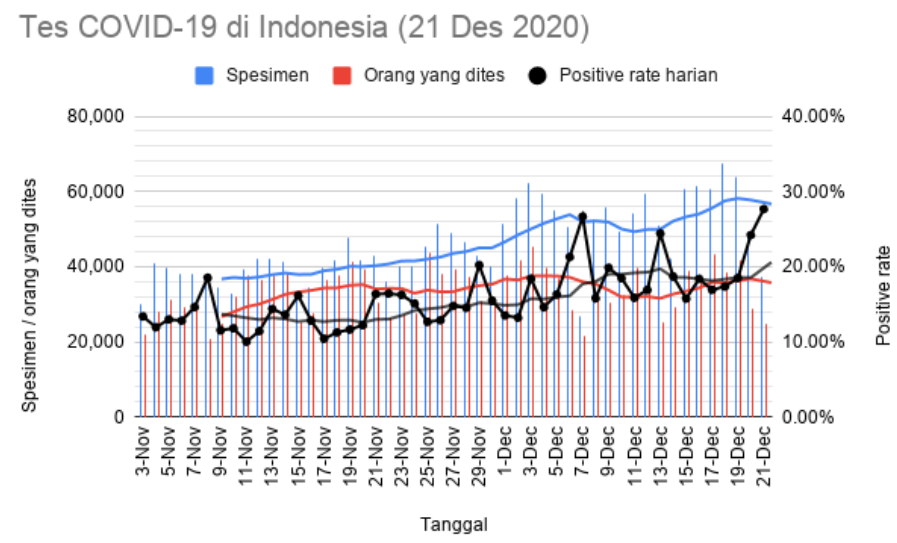

Gambar 1. Grafik Kenaikan Covid-19 Periode 2020 
Epidemiologi Griffith University Australia Dicky Budiman mengatakan, kondisi pandemi Covid-19 di Indonesia saat ini semakin serius dan memprihatinkan. Hal ini bisa dilihat dari data epidemiologi yang menunjukkan peningkatan tren kasus infeksi Covid-19 harian, kematian, dan hunian rumah sakit atau kasus aktif. Kondisi saat ini sudah semakin serius dan memprihatinkan dengan semua tren yang semakin meningkat, dari angka infeksi hingga hunian rumah sakit.

\section{Cafe}

Persaingan pada bisnis makanan yang ketat terutama pada usaha cafe saat ini mengharuskan pelaku usaha mempunyai keunggulan kompetitif. Karena itu suasana pada cafe harus terencana pada toko yang sesuai dengan sasarannya dan dapat menarik pelanggan yang secara tidak langsung merangsang konsumen untuk melakukan pembelian dan merasa puas dan kembali mengulang-ulang pembelian. Menurut Utami (2010:279). Pada Cafe Jolly Coffee ini sudah menerapkan suasana yang nyaman dan baik di tengah pandemi covid-19 saat ini juga pengupayaan makanan yang enak tetapi tetap sehat untuk dikonsumsi. Salah satu contohnya pada gambar 2, 3, 4 dan 5 berikut ini:

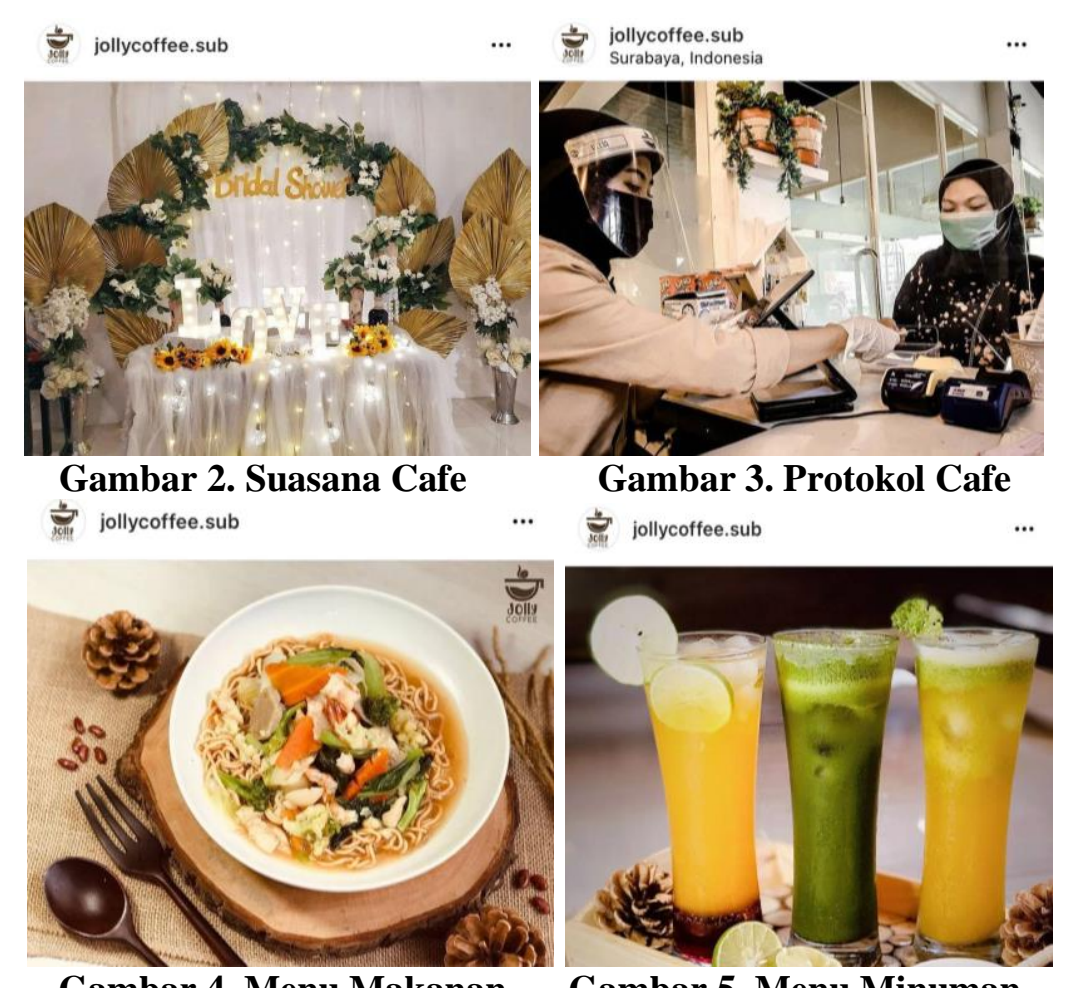

Gambar 4. Menu Makanan

Gambar 5. Menu Minuman 
Selain itu juga pada Cafe Jolly Coffee sering mengadakan promo menarik setiap hari jumat yaitu potongan sebesar $20 \%$ untuk pembelian apapun, dimana hal itu dilakukan sebagai bentuk promosi agar Cafe Jolly Coffee lebih dikenal oleh masyarakat secara luas dan untuk tetap menjaga jarak aman agar mengurangi penyebaran covid-19 juga diberikannya handsinitizer di setiap meja, tempat cuci tangan sebelum masuk kedalam cafe, serta pengecekan suhu sebelum masuk ke dalam Cafe Jolly Coffee.

\section{METODE PENELITIAN}

Jenis penelitian yang digunakan dalam penelitian ini adalah penelitian deskriptif dengan pendekatan kualitatif yaitu menggunakan studi pustaka atau literatur yang ada dengan menggunakan buku, jurnal, dan web yang relevan dengan penelitian. Penelitian deskriptif berkaitan dengan pengumpulan data untuk memberikan gambaran atau penegasan suatu konsep atau gejala, juga menjawab pertanyaan-pertanyaan sehubungan dengan status subjek penelitian pada saat ini, misalnya sikap atau pendapat terhadap individu, organisasi atau sebagainya.

Pendekatan yang digunakan pada penelitian ini adalah pendekatan kualitatif yaitu pendekatan penelitian tanpa menggunakan angka statistik tetapi dengan pemaparan secara deskriptif yaitu berusaha mendeskripsikan suatu gejala, peristiwa, kejadian yang terjadi di saat sekarang, di mana peneliti berusaha memotret peristiwa dan kejadian yang terjadi menjadi focus perhatiannya untuk kemudian dijabarkan sebagaimana adanya.

Teknik pengumpulan data yang digunakan adalah observasi, wawancara, dan studi dokumentasi. Menurut (Sugiyono, 2016) menyatakan bahwa wawancara digunakan sebagai teknik pengumpulan data apabila peneliti ingin melakukan studi pendahuluan untuk menemukan masalah permasalahan yang harus diteliti, tetapi juga apabila ingin mengetahui hal-hal dari responden yang lebih mendalam.

Wawancara dilakukan dengan para narasumber (informan) baik pemilik cafe manajer cafe maupun konsumen, serta dari hasil observasi pada media online. Kemudian mengidentifikasi serta merumuskan masalah yang ada, dan data diuji menggunakan uji kevalidan data menggunakan triangulasi sumber.

Teknik analisis data menggunakan analisis kualitatif yaitu proses secara sistematis untuk mengkaji dan mengumpulkan transkrip wawancara, catatan lapangan, dokumentasi, dan hal-hal lain untuk memperdalam pemahaman tentang fokus penelitian, baik dari hasil observasi, wawancara maupun dokumentasi catatan lapangan, dokumentasi, dan hal-hal lain untuk memperdalam pemahaman tentang fokus penelitian, baik dari hasil observasi, wawancara maupun dokumentasi untuk dijadikan sebuah temuan penelitian. Analisis data yang digunakan dalam penelitian 
ini adalah teknik analisis model interaktif yang dikembangkan oleh (Miles, M.B, Huberman, A.M, dan Saldana, 2014) yang terdiri dari reduksi data, penyajian data, dan penarikan kesimpulan.

\section{HASIL DAN PEMBAHASAN}

Usaha makanan dalam bentuk cafe atau restoran menjadi salah satu jenis usaha yang sangat potensial dimana memang makanan merupakan hal yang wajib dilakukan oleh setiap makhluk hidup agar tetap bertahan hidup. Cafe Jolly Coffee ini dianggap cafe yang relatif terjangkau dari segi harga dengan pelayanan dan fasilitas yang sangat bagus sehingga pengunjung atau konsumen selalu ramai. Masa kejayaan bisnis Cafe Jolly Coffee adalah saat pengunjung ramai berdatangan hingga banyaknya permintaan reservasi tempat untuk acara khusus di cafe ini. Namun sayangnya pada periode tahun 2018-2020 volume penjualan dan pendapatan mengalami penurunan. Berikut akan dijelaskan volume penjualan dan pendapatan Cafe Jolly Coffee Surabaya.

Tabel 1.

Volume Penjualan dan Pendapatan Cafe Jolly Coffee

\begin{tabular}{|c|c|c|c|}
\hline \multirow{2}{*}{} & \multicolumn{3}{|c|}{ Periode Tahun } \\
\cline { 2 - 4 } & 2018 & 2019 & 2020 \\
\hline Konsumen (orang) & 10.064 & 8.754 & 5.423 \\
\hline Pendapatan (juta) & 364.283 & 237.208 & 93.987 \\
\hline
\end{tabular}

Sumber: Cafe Jolly Coffee Periode 2018-2020

Tabel menunjukkan adanya penurunan jumlah kedatangan konsumen yang berpengaruh pada menurunnya penjualan makanan maupun minuman dari tahun 2018 hingga ke tahun 2020. Penjualan tahun 2019 menurun sebesar 28\% dibanding 2018, sedangkan di tahun 2020 mengalami penurunan sangat drastis dibandingkan tahun sebelumnya. Hal ini berdampak pada penurunan pendapatan yang cukup signifikan, apalagi saat pandemi Corona (Covid-19) yang melanda Indonesia mulai awal bulan Maret 2020, penjualan ikut menurun tajam. Sehingga menyebabkan pendapatan serta harga jual ikut menurun yang menyebabkan manajemen pemasaran harus memikir strategi terbaik dalam menangani hal tersebut.

Strategi Marketing Mix yang di terapkan pada Cafe Jolly Coffee Surabaya menggunakan bauran pemasaran yang diterapkan pada Cafe terdiri dari $7 \mathrm{P}$ dengan penjelasan sebagai berikut:

\section{Product (Produk)}

Produk yang ditawarkan oleh pihak Cafe Jolly Coffee Surabaya antara lain berupa makanan dan aneka minuman yang mengarah ke bentuk dari modernisasi 
makanan dan minuman tersebut. Dengan penamaan yang mengambil istilah bahasa Inggris dan juga perubahan model atau bentuk dari makanan dan minuman di Cafe Jolly Coffee Surabaya. Selain itu banyaknya menu seperti makanan khas jepang maupun khas Indonesia asli, lalu adanya menu produk baru seperti jus yang menyehatkan maupun makanan yang mengandung sayur seperti capcai ini dilakukan karena adanya covid-19 menjadikan kita harus hidup sehat sehingga harus mengkonsumsi makanan yang bergizi.

\section{Price (Harga)}

Penetapan harga dalam suatu pelaku bisnis akan menentukan posisi persaingan dan mempengaruhi tingkat penjualan produk. Penetapan harga juga yang bisa jadi tombak ukur dalam konsumen sekitar untuk melihat apakah harga yang ditawarkan terjangkau atau tidak. Pada Cafe Jolly Coffee sudah berupaya dalam memberikan harga yang terjangkau dengan citra rasa dan fasilitas yang diberikan. Pada covid-19 ini seringnya Cafe Jolly Coffee memberikan potongan harga setiap hari jumat sebesar $20 \%$ dan berlaku untuk pembelian apapun serta pembelian secara langsung maupun online karena mengingat ekonomi atau pendapatan masyarakat Indonesia berkurang karena adanya pandemi covid-19 yang banyaknya mengalami penurunan gaji atau pendapatan hingga pada pengurangan jumlah pekerja.

\section{Promotion (Promosi)}

Jenis Promosi yang dilakukan oleh pihak Cafe Jolly Coffee Surabaya yaitu Personal selling, merupakan penyajian secara lisan dalam suatu pembicaraan dengan seorang atau lebih kepada calon pembeli dengan tujuan agar mendapatkan konsumen. Selain itu, dalam mempromosikan juga menggunakan media-media online dikarenakan media online menyebarkan informasi lebih cepat dari media yang lainnya. Pada masa covid-19 Cafe Jolly Coffee memberikan promosi dengan diskon atau potongan harga, serta makanan dengan paket bundling selain itu juga adanya promosi pada media sosial instagram maupun tiktok untuk menarik konsumen baru.

\section{Place (Tempat)}

Pihak Cafe Jolly Coffee Surabaya juga menargetkan kalangan anak muda dan juga para influencer yang ingin mereview nuansa dari Cafe Jolly Coffee Surabaya. Bukan tanpa alasan menargetkan para anak muda karena di era sekarang yang lebih maju berkat teknologi di bidang internet maka perlu adanya influencer dari para kalangan muda untuk memikat lebih banyak peminat berkat review penilaian, dan juga spot foto yang Instagramable. Namun karena terfokus pada jaga jarak aman guna mengurangi penyebaran covid-19 sehingga tempat duduk diberikan jarak dan tempat spot foto dilarang untuk digunakan secara bersama-sama. 


\section{People (Orang)}

Dalam perekrutan karyawan hanya berdasarkan keterampilan dasar saja sehingga apabila mulai bekerja karyawan baru diberikan pelatihan khusus guna meningkatkan skill, sebab hal yang paling utama agar konsumen puas dan loyal adalah pada makanan dan minuman serta pelayanan yang baik. Terlebih Cafe Jolly Coffee cukup terkenal di Surabaya. Selain itu setiap harinya karyawan akan selalu diperiksa suhu badannya begitupun konsumennya yang turut di cek suhu ketika ingin memasuki Cafe Jolly Coffee.

\section{Process (Proses)}

Bisnis tidak luput dari kesalahan, seperti hal nya pada bisnis Cafe Jolly Coffee yang sering terjadi yakni pada proses pembayaran ataupun saat proses memesan sehingga sering terjadinya kurang komunikasi antara karyawan misalnya kasir dengan pelayan. Walaupun demikian pihak Cafe Jolly Coffee akan terus meningkatkan sikap profesionalisme terhadap individu karyawannya, selain itu juga demi mengurangi kesalahan serta kontak fisik maka metode pembayaran diubah menggunakan pembayaran online virtual account seperti lewat dana, ovo, gopay, dan lain-lain.

\section{Physical Evidence (Bukti Fisik)}

Bukti fisik yang diberikan Cafe Jolly Coffee ini adalah berupa fasilitas bagi para konsumennya dengan tujuan agar konsumen mendapatkan kenyamanan dan kepuasan. Cafe Jolly Coffee memanjakan konsumennya melalui fasilitas-fasilitas yang disediakan seperti berbagai macam model kursi yang nyaman, wi-fi, live music, tempat foto, Musallah, meeting room (untuk pertemuan standar seperti persentasi, reuni arisan dan ulang tahun) dan ex meeting room (untuk pertemuan bisnis formal). Namun karena terkendala covid-19 sehingga pengurangan tempat yang memicu berkumpulnya banyak orang menjadi dibatasi.

Cafe Jolly Coffee selalu berusaha memposting produk-produknya dengan menarik melalui feed di instagram, instastory maupun video yang sudah diedit di tiktok guna memperluas informasi Cafe Jolly Coffee kepada masyarakat secara meluas. Menu pada Instagram dan Tiktok diberikan fasilitas bagi konsumen untuk memberikan komentar dan respon seputar pengalamannya dengan produk-produk yang disediakan maupun fasilitas yang diberikan Cafe Jolly Coffee. Pengunjung dapat memberikan komentar secara langsung di bawah materi postingan, sehingga pengunjung yang lain maupun konsumen baru dapat mengolah informasi tersebut untuk mempertimbangkan melalukan pembelian di Cafe Jolly Coffee Surabaya karena memang tidak dapat dipungkiri bahwa penilaian mampu membawa dampak citra perusahaan. Berikut ini hasil dari analisis tanggapan konsumen tentang Cafe Jolly Coffee Surabaya. 
Tabel 2.

Hasil Analisis Tanggapan Konsumen

\begin{tabular}{|c|c|c|c|c|c|}
\hline Pertanyaan & \multicolumn{5}{|c|}{ Alternatif Jawaban (N/\%) } \\
\hline $\begin{array}{l}\text { Alasan utama } \\
\text { membeli pada } \\
\text { Cafe Jolly } \\
\text { Coffee }\end{array}$ & $\begin{array}{c}\text { Lebih } \\
\text { murah dan } \\
\text { enak } \\
58 \%\end{array}$ & $\begin{array}{l}\text { Variasi } \\
\text { menu } \\
\text { makanan } \\
21 \%\end{array}$ & $\begin{array}{c}\text { Lebih } \\
\text { mudah } \\
\text { diperoleh } \\
13 \%\end{array}$ & $\begin{array}{c}\text { Makanan } \\
\text { sehat serta } \\
\text { bergizi } \\
8 \%\end{array}$ & Lainnya.... \\
\hline $\begin{array}{c}\text { Keputusan } \\
\text { pembelian } \\
\text { pada Cafe Jolly } \\
\text { Coffee }\end{array}$ & $\begin{array}{c}\text { Terencana/ } \\
\text { terjadwal } \\
17 \%\end{array}$ & $\begin{array}{c}\text { Tergantung } \\
\text { kebutuhan } \\
33 \%\end{array}$ & $\begin{array}{c}\text { Pembelian } \\
\text { berkala } \\
8 \%\end{array}$ & $\begin{array}{c}\text { Pembelian } \\
\text { spontan } \\
42 \%\end{array}$ & $\begin{array}{c}\text { Lainnya... } \\
-\end{array}$ \\
\hline $\begin{array}{c}\text { Jumlah } \\
\text { transaksi } \\
\text { pembelian } \\
\text { pada Cafe Jolly } \\
\text { Coffee } \\
\end{array}$ & $\begin{array}{c}\begin{array}{c}\text { Kurang } \\
\text { dari } 50.000 \\
18 \%\end{array} \\
\end{array}$ & $\begin{array}{c}\text { Lebih dari } \\
50.000 \\
41 \%\end{array}$ & $\begin{array}{c}\text { Lebih dari } \\
100.000 \\
33 \%\end{array}$ & $\begin{array}{c}\text { Lebih dari } \\
500.000 \\
6 \%\end{array}$ & $\begin{array}{c}\text { Lebih dari } \\
1.000 .000 \\
2 \%\end{array}$ \\
\hline $\begin{array}{c}\text { Lokasi } \\
\text { pembelian } \\
\text { pada Cafe Jolly } \\
\text { Coffee }\end{array}$ & $\begin{array}{c}\text { Secara } \\
\text { langsung } \\
29 \%\end{array}$ & $\begin{array}{c}\text { Dibawa } \\
\text { pulang } \\
24 \%\end{array}$ & $\begin{array}{c}\text { Media } \\
\text { Online } \\
38 \%\end{array}$ & $\begin{array}{c}\text { Melalui } \\
\text { Jasa Titip } \\
9 \%\end{array}$ & $\begin{array}{c}\text { Lainnya... } \\
\text { - }\end{array}$ \\
\hline $\begin{array}{c}\text { Pertimbangan } \\
\text { pemilihan } \\
\text { tempat } \\
\text { pembelian }\end{array}$ & $\begin{array}{c}\text { Harga } \\
\text { terjangkau } \\
31 \%\end{array}$ & $\begin{array}{c}\text { Lokasi } \\
\text { strategis } \\
14 \%\end{array}$ & $\begin{array}{c}\text { Bersih dan } \\
\text { higienis } \\
26 \%\end{array}$ & $\begin{array}{c}\text { Fasilitas } \\
\text { bagus } \\
29 \%\end{array}$ & $\begin{array}{c}\text { Lainnya... } \\
\text { - }\end{array}$ \\
\hline $\begin{array}{l}\text { Pengalaman } \\
\text { membeli } \\
\text { online di Cafe } \\
\text { Jolly Coffee }\end{array}$ & $\begin{array}{l}\text { Selalu } \\
16 \%\end{array}$ & $\begin{array}{c}\text { Sering } \\
34 \%\end{array}$ & $\begin{array}{c}\text { Pernah } \\
29 \%\end{array}$ & $\begin{array}{c}\text { Kadang } \\
21 \%\end{array}$ & $\begin{array}{c}\text { Tidak Pernah } \\
-\end{array}$ \\
\hline $\begin{array}{c}\text { Alasan } \\
\text { membeli pada } \\
\text { Cafe Jolly } \\
\text { Coffee }\end{array}$ & $\begin{array}{c}\text { Mudah dan } \\
\text { cepat } \\
21 \%\end{array}$ & $\begin{array}{c}\text { Harga sudah } \\
\text { pasti } \\
23 \%\end{array}$ & $\begin{array}{c}\text { Pelayanan } \\
\text { baik } \\
27 \%\end{array}$ & $\begin{array}{c}\text { Cita rasa } \\
\text { enak } \\
29 \%\end{array}$ & $\begin{array}{c}\text { Lainnya... } \\
\text { - }\end{array}$ \\
\hline $\begin{array}{c}\text { Informasi } \\
\text { keberadaan } \\
\text { penjualan Cafe } \\
\text { Jolly Coffee }\end{array}$ & $\begin{array}{c}\text { Instagram } \\
39 \%\end{array}$ & $\begin{array}{c}\text { TikTok } \\
32 \%\end{array}$ & $\begin{array}{c}\text { Internet } \\
4 \%\end{array}$ & $\begin{array}{c}\text { Grup WA } \\
16 \%\end{array}$ & $\begin{array}{c}\text { Teman/saudara } \\
9 \%\end{array}$ \\
\hline $\begin{array}{c}\text { Kejelasan iklan } \\
\text { penjualan pada } \\
\text { Cafe Jolly } \\
\text { Coffee }\end{array}$ & $\begin{array}{l}\text { Sangat } \\
\text { jelas } \\
58 \%\end{array}$ & $\begin{array}{l}\text { Jelas } \\
27 \%\end{array}$ & $\begin{array}{l}\text { Cukup } \\
\text { jelas } \\
12 \%\end{array}$ & $\begin{array}{c}\text { Kurang } \\
\text { jelas } \\
3 \%\end{array}$ & $\begin{array}{c}\text { Tidak Jelas } \\
-\end{array}$ \\
\hline $\begin{array}{l}\text { Yang disukai } \\
\text { dari iklan } \\
\text { online pada } \\
\text { Cafe Jolly } \\
\text { Coffee } \\
\end{array}$ & $\begin{array}{c}\text { Respons } \\
\text { cepat } \\
17 \%\end{array}$ & $\begin{array}{c}\text { Layanan } \\
\text { pesan antar } \\
23 \%\end{array}$ & $\begin{array}{c}\text { Informasi } \\
\text { harga jelas } \\
4 \%\end{array}$ & $\begin{array}{c}\text { Banyak } \\
\text { varian menu } \\
22 \%\end{array}$ & $\begin{array}{c}\text { Promosi \& } \\
\text { potongan harga } \\
34 \%\end{array}$ \\
\hline
\end{tabular}


Siti Nur Wahyu Ningsih, Aida Octavia Milasari, Muchammad Saifuddin

Strategi Marketing Mix Dalam Menghadapi Pandemi Covid-19 (Studi Kasus

\section{Pada Cafe Jolly Coffee Surabaya)}

Jurnal MANOVA Volume IV Nomor 1, P ISSN : 2685-4716, E ISSN : 2746-282X
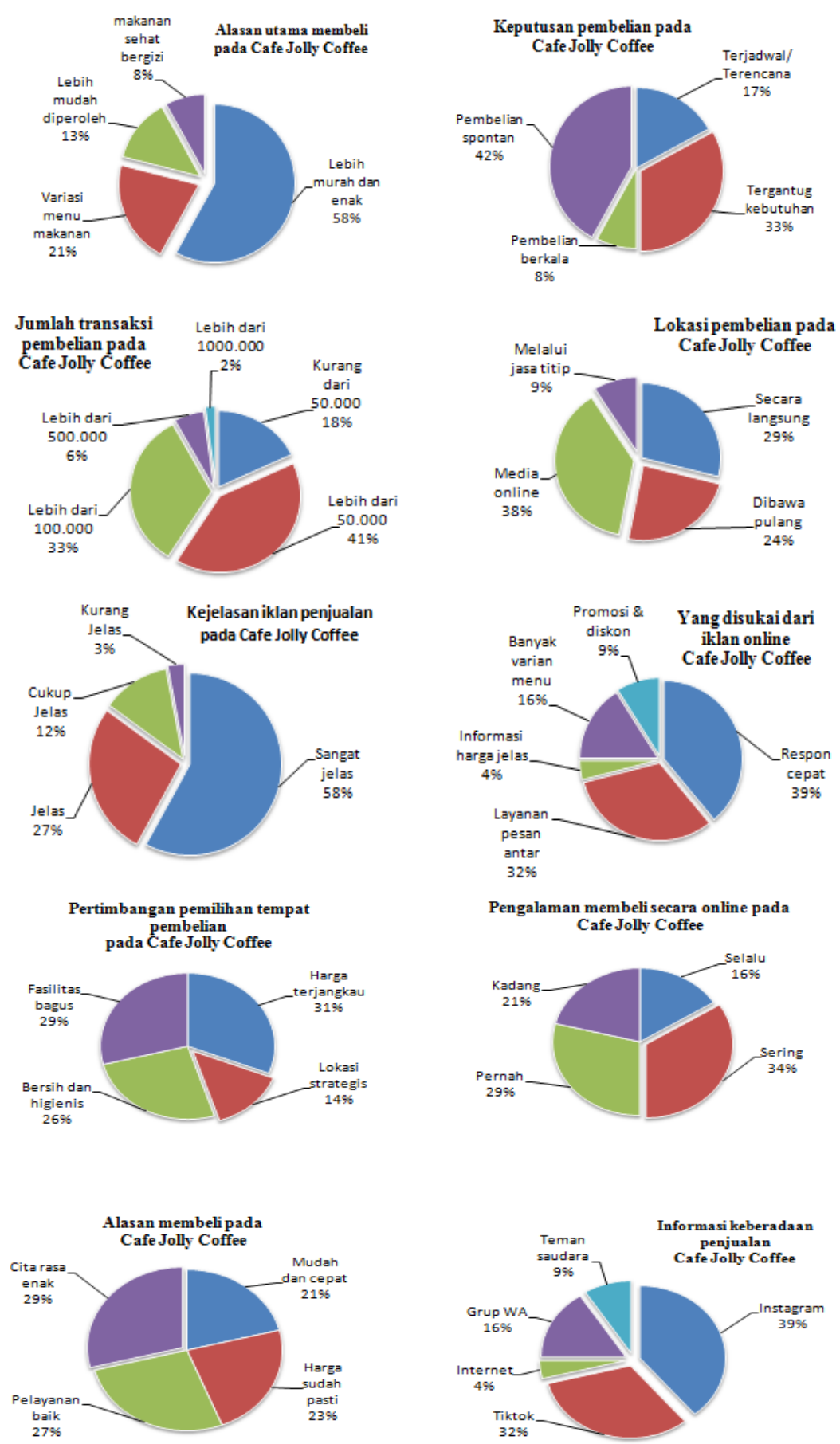

\section{Gambar 6. Pie Chart Hasil Analisis Tanggapan Konsumen}


Dapat diketahui bahwa alasan utama konsumen membeli pada Cafe Jolly Coffee sebagian besar adalah karena lebih murah dan enak (58\%). Kemudian keputusan Cafe Jolly Coffee dilakukan adalah pembelian spontan (42\%). Jumlah pembelian pada Cafe Jolly Coffee setiap transaksi sebagian besar adalah lebih dari Rp. 50.000 (41\%). Adapun lokasi tempat pembelian Cafe Jolly Coffee setiap yang biasanya dituju konsumen adalah secara langsung (29\%) dan media online seperti go-food (38\%). Pertimbangan yang dipilih konsumen saat pemilihan tempat pembelian adalah karena harga yang terjangkau (31\%) dan fasilitas bagus (29\%). Ditinjau dari pengalaman konsumen membeli secara online pada Cafe Jolly Coffee konsumen menjawab sering membeli secara online (34\%) dan pernah (29\%). Alasan membeli pada Cafe Jolly Coffee secara online adalah karena citra rasa enak (29\%) serta pelayanan baik (27\%). Konsumen memperoleh informasi tentang keberadaan penjualan Cafe Jolly Coffee sebagian besar dari Instagram (39\%) selanjutnya dari TikTok (32\%). Tanggapan konsumen tentang kejelasan iklan penjualan Cafe Jolly Coffee di media online adalah sudah sangat jelas (58\%). Adapun hal yang paling disukai dari iklan Cafe Jolly Coffee adalah karena promosi dan potongan harga (34\%), adanya layanan pesan antar (23\%), dan banyaknya varian menu (22\%). Berikut merupakan gambaran dari hasil analisis alasan konsumen melakukan pembelian di Cafe Jolly Coffee yang dapat dilihat pada gambar 7.

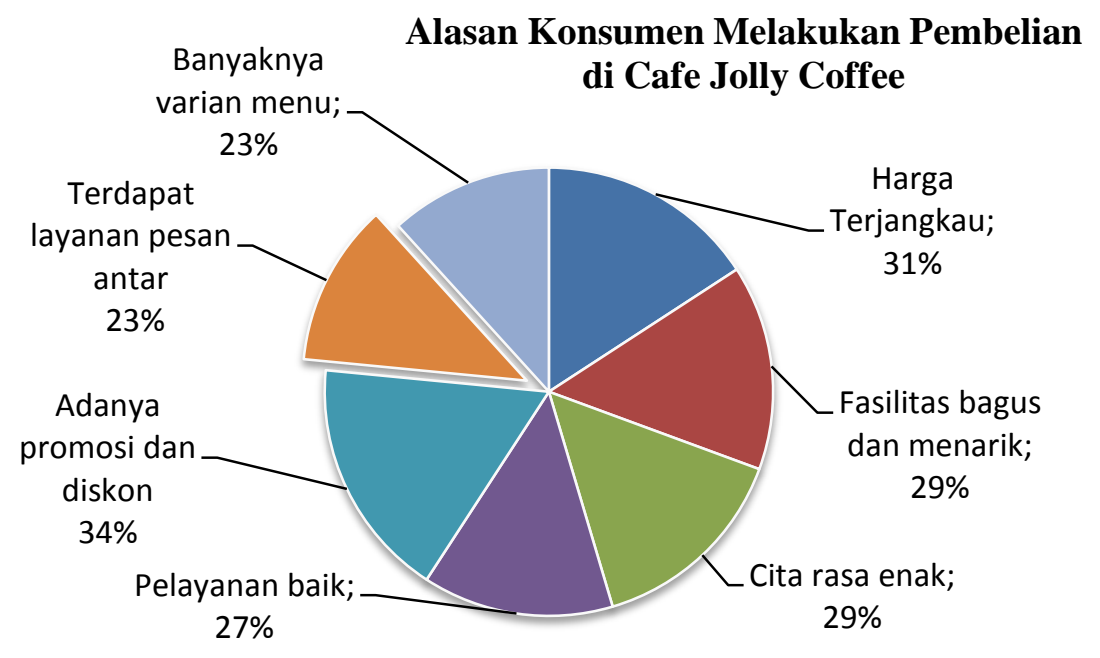

\section{Gambar 7. Pie Chart Alasan Konsumen Melakukan Pembelian di Cafe Jolly Coffee}


Berbagai keuntungan dari penggunaan strategi ini antara lain promosi yang lebih cepat dan jangkauannya lebih melebar luas. Di media sosial seseorang bisa mempromosikan suatu produk juga lebih mudah, tinggal memasang gambar atau foto dari produk yang akan dipasarkan dengan diberi beragam uraian penjelasan seperti harga yang ditawarkan, kemudian gambar atau foto tersebut di tag atau dikirim ke semua teman-teman dalam komunitas nya. Dengan begitu iklan tersebut langsung dapat diterima oleh semua teman dalam komunitas tadi. Artinya informasi dapat tersebar dengan lebih cepat dan daya jangkau yang luas.

\section{KESIMPULAN}

Pembahasan dalam penulisan ini penulis menyimpulkan mengenai strategi Marketing Mix dalam pemasaran Cafe Jolly Coffee Surabaya adalah sebagai berikut:

1. Cafe Jolly Coffee Surabaya telah membagi secara khusus segmen pasar mereka. Namun berdasarkan produk yang ditawarkan diperuntukkan untuk kalangan anak muda atau mungkin juga untuk kalangan pebisnis. Artinya Cafe Jolly Coffee Surabaya dapat menentukan segmentasi pasar berdasarkan demografis, yaitu segmentasi yang dibagi untuk menjadikan kelompok berlandaskan variabel tertentu seperti jenis kelamin, pekerjaan maupun usia.

2. Cafe Jolly Coffee Surabaya mempunyai target pasar yang dikhususkan untuk menjadi prioritas dalam memasarkan produk yang mereka jual, dengan membidik semua kalangan khususnya para pebisnis dan juga influencer dari kalangan muda. Berdasarkan hal tersebut maka pendekatan yang dapat dilakukan yaitu dengan pembidikan pasar berbasis diferensiasi produk. Strategi pembidikan pemasaran ini sering dilakukan ketika segmen pasar tidak dapat diidentifikasi dengan jelas.

3. Harga yang ditawarkan Cafe Jolly Coffee Surabaya untuk produk yang dijual relatif terjangkau dibandingkan dengan pesaing yang menjual produk yang sejenis. Pada dasarnya posisi Cafe Jolly Coffee Surabaya memiliki pesaing yang banyak dengan harga dan fasilitas yang hampir sama.

4. Strategi pemasaran yang dilakukan untuk lokasi serta promosi yang dilakukan dalam memasarkan produk yang dijual sudah cukup baik. Penempatan posisi pasar yang dilakukan oleh supaya produk maupun nama cafe dapat diingat dan menjadi tempat tersendiri di benak konsumen dengan cara menentukan produk yang relevan serta memosisikan produk yang dijual supaya dapat digunakan oleh semua kalangan. Mendata produk yang diinginkan konsumen berdasarkan kebutuhan, dan serta mengidentifikasi pesaing dengan cara melakukan inovasi terhadap produk yang dijual. 
Dari hasil dan pembahasan serta kesimpulan diatas, maka dapat disimpulkan saran bagi Cafe Jolly Coffee Surabaya sebagai berikut:

1. Dalam memperoleh segmentasi pasar yang luas sebaiknya Cafe Jolly Coffee Surabaya melakukan kerja sama dengan para influencer agar mendapatkan produknya dikenal oleh konsumen yang lebih luas lagi. Karena bagaimanapun influencer saat ini mampu meracuni penggemarnya untuk mengikuti apapun yang dilakukan influencer tersebut.

2. Cafe Jolly Coffee Surabaya sebaiknya menyediakan berbagai macam harga yang perlu ditampilkan di cafe ataupun media online agar dapat dijangkau semua kalangan. Tersedianya produk yang ditampilkan dengan berbagai harga yang dapat memperluas target pasar Cafe Jolly Coffee Surabaya. Agar posisi Cafe Jolly Coffee Surabaya di mata konsumen dan para pesaing memiliki nilai lebih. Karena menu harga saat ini hanya dituliskan di highlight instagram saja sehingga jika konsumen dari aplikasi media online lainnya seperti tiktok akan kurang informasi menu harganya.

3. Cafe Jolly Coffee Surabaya tetap harus mempertahankan kualitas produk yang dijual, kenyamanan dari cafe itu sendiri, serta fasilitas yang diberikan. Selain itu tetap harus memperluas promosi dengan ikut serta perkembangan terkini agar nama Cafe Jolly Coffee Surabaya lebih dikenal masyarakat secara luas.

4. Peneliti menyadari masih banyak kekurangan dalam penulisan, maka diharapkan untuk peneliti selanjutnya dapat melanjutkan penelitian ini dengan mengukur dari segi aspek yang berbeda dan metodologi yang berbeda.

\section{DAFTAR PUSTAKA}

Ali, H. (2013). Marketing dan Kasus-kasus Pilihan. Center For Academic: Publishing Sevice.

Assauri, S. (2014). Manajemen Pemasaran. Jakarta: Raja Grafindo Persada.

Dzulfaroh, Naufal Ahmad. (2020). Selama Desember 2020, Tren Kesembuhan Menurun, Infeksi dan Kematian Naik. (Selama Desember 2020, Tren Kesembuhan Covid-19 di Indonesia Menurun, Infeksi dan Kematian Naik (kompas.com), diakses pada tanggal 26 Desember 2020.

Farellya, Faustine, Sriti M.S.\&Stephanie M.F. 2017. Penerapan Eko-Interior pada

Restoran Merah Putih di Bali. JURNAL INTRA. 5(2): 197-203

Hartanti, \& Rina O. Pengembangan Strategi Pemasaran Ayam Barokah Melalui Digital Marketing. Jurnal Sekretari dan Manajemen. 4(2): 183-190.

Kementerian Penanganan Covid-19 dan Pemulihan Ekonomi Nasional. (2020). Peta Sebaran Covid-19. (https://covid19.go.id/peta-sebaran-covid19, diakses pada tanggal 26 Desember 2020)

Kotler, P. \& Keller, K. (2019). Manajemen Pemasaran 13th ed. Jakarta: Erlangga.

Lestari, P. \& Muchammad Saifuddin. (2020). Implementasi Strategi Promosi Produk Dalam Proses Keputusan Pembelian Melalui Digital Marketing Saat Pandemi Covid-19. Jurnal Manajemen dan Inovasi (MANOVA). 3(2): 23-31. 
Marhadi, N.A. \& Henni N. 2013. Pengaruh Strategi Green marketing pada Bauran Pemasaran terhadap Keputusan Konsumen dalam Membeli Rumah di Perumahan Pt. Asta Karya Pekan Baru. Jurnal Ekonomi. 21(3): 89.

Oetman, F., (2017), Analisis Bauran Pemasaran di Hotel Sasando Kupang. Jurnal AGORA. 5(3): 72.

Pomantouw, G.V. Mananeke, L. \& Jorie, J.R. (2019). Analisis Segmentasi, Targeting, dan Positioning Terhadap Keputusan Pembelian Produk Maxx Coffee di Hotel Aryaduta Manado. Jurnal EMBA. 7(4): 56.

Rohmi, Aida Nur. (2020). Pandemi Belum Berakhir, Bagaimana Perekonomian Indonesia pada 2021?. Kompas.com. (https://www.kompas.com/tren/read/2020/12/18/100600765/pandemi-belumberakhir-bagaimana-perekonomian-indonesia-pada-2021-?page=all, diakses pada 26 Desember 2020)

Setiadi, N.J. (2003). Perilaku Konsumen: Konsep dan Implikasi Untuk Strategi dan Penelitian Pemasaran. Jakarta: Prenada Media.

Stanton, J. (2010). Prinsip-prinsip Pemasaran 17th ed. Jakarta: Erlangga, 2010.

Sugiyono. (2014). Metode Penelitian Kuantitatif, Kualitatif dan R\&D, (Bandung: CV Alfabeta.

Sumarni, M. \& Soeprihanto, J. (2010). Pengantar Bisnis (Dasar-dasar Ekonomi Perusahaan) 5th ed. Yogyakarta: Liberty.

Tjiptono, F. (2002). Strategi Pemasaran, Yogyakarta: Andi.

Widjaya, P.G. (2017). Analisis Segmenting, Targeting, Positioning dan Marketing Mix Pada PT. Murni Jaya. Jurnal AGORA. 5(1): 93.

Wiyadi. (2015). Pengaruh Implementasi Strategi Pemasaran Hijau Dan Karakteristik Konsumen Terhadap Pilihan Produk (Studi Empiris Pada Konsumen Amdk Di Surakarta). Jurnal Manajemen dan Bisnis.19(2): 168180. 